\title{
Anthelmintic activity of the ethanol extract of the Uncaria guianensis (Rubiaceae) on eggs and larvae of gastrointestinal nematodes of sheep in the Western Amazon Region
}

\author{
Atividade anti-helmíntica do extrato de etanol de Uncaria guianensis (Rubiaceae) \\ em ovos e larvas de nematoides gastrintestinais de ovinos na região da \\ Amazônia Ocidental
}

\author{
Sara Lucena Amorim ${ }^{1 *}$ (D), Alex Cicinato Paulino de Oliveira² (D), Renato Mesquita Peixoto ${ }^{3}$, \\ Lucas da Silva Bastos ${ }^{1}$ (D) Wilson Wouflan Silva ${ }^{4}$, Ana Célia Rodrigues Athayde ${ }^{4}$ (1)
}

\begin{abstract}
The purpose of this study was to evaluate the anthelmintic effect of the root and stem of Uncaria guianensis on eggs and larvae of gastrointestinal nematodes from naturally infected sheep. The extract of the root of Uncaria guianensis was tested at concentrations of $0.57 \mathrm{mg} / \mathrm{mL}$ and $1.14 \mathrm{mg} / \mathrm{mL}$ and the extract of the stem of Uncaria guianensis at concentrations of $1.25 \mathrm{mg} / \mathrm{mL}$ and $2.5 \mathrm{mg} / \mathrm{mL}$. The animals were divided in groups of five animals each, where four groups received the plant extract and a dose / concentration, one group received the anti-helminthic closantel and another group received only distilled water, totaling six treated groups. Ten $\mathrm{mL}$ were applied orally on days treatment, in a single dose for the groups treated with the extract, the closantel group received the dose recommended by the manufacturer and the negative group received $10 \mathrm{~mL}$ of distilled water. Stool samples were collected weekly for parasitological analysis and blood for hematocrit. The results of the OPG were analyzed after log transformation $(x+1)$ and submitted to one-way analysis of variance (ANOVA) and Tukey's test at 5\% of probability. Third stage L3 larvae were recovered from co-culture and subjected to the 5\% tukey test. The results showed a reduction in the number of eggs per gram of feces, in the group treated with Uncaria guianensis root at a concentration of $1.14 \mathrm{mg} / \mathrm{mL}$ and in the chemically treated group, where they obtained a statistically significant reduction ( $\mathrm{p}<5 \%$ ), when compared to the other treated groups, presenting $69 \%$ and $66 \%$ respectively in the reduction percentage. Regarding the number of third-stage larvae of gastrointestinal nematodes recovered from sheep, after treatment they observed that the groups treated with closantel, Uncaria guianensis root at a concentration of $1.14 \mathrm{mg} / \mathrm{mL}$ and a stem of Uncaria guianensis at a concentration of $1.25 \mathrm{mg} / \mathrm{mL}$ were statistically different $(\mathrm{p}<5 \%)$ from the other treatments, with $68 \%, 68 \%$ and $86 \%$ respectively reduction in the number of larvae. As for the hematocrit, the results remained within the reference standards for the Amazon Biome. Thus, we conclude that Uncaria guianensis has ovicidal and larvicidal activity on gastrointestinal nematodes in sheep.
\end{abstract}

KEYWORDS: endoparasites, phytotherapy, small ruminants.

RESUMO: O objetivo deste estudo foi avaliar o efeito anti-helmíntico da raiz e do caule de Uncaria guianensis sobre ovos e larvas de nematóides gastrointestinais de ovelhas naturalmente infectadas. $\mathrm{O}$ extrato da raiz de Uncaria guianensis foi testado nas concentrações de $0,57 \mathrm{mg} / \mathrm{mL}$ e $1,14 \mathrm{mg} / \mathrm{mL}$ e o extrato do caule de Uncaria guianensis nas concentraçóes de $1,25 \mathrm{mg} / \mathrm{mL}$ e $2,5 \mathrm{mg} / \mathrm{mL}$. Os animais foram divididos em grupos de cinco animais cada, onde quatro grupos receberam o extrato vegetal e uma dose / concentração, um grupo recebeu o anti-helmíntico closantel e outro grupo recebeu apenas água destilada, totalizando seis grupos tratados. Foram aplicados dez $\mathrm{mL}$ por via oral nos dias de tratamento, em dose única para os grupos tratados com o extrato, o grupo closantel recebeu a dose preconizada pelo fabricante e o grupo negativo recebeu $10 \mathrm{~mL}$ de água destilada. Amostras de fezes foram coletadas semanalmente para análise parasitológica e sangue para hematócrito. Os resultados do OPG foram analisados após transformação logarítmica $(\mathrm{x}+1)$ e submetidos à análise de variância unilateral (ANOVA) e teste de Tukey a 5\% de probabilidade. As larvas L3 de terceiro estágio foram recuperadas da co-cultura e submetidas ao teste de tukey a 5\%. Os resultados mostraram uma reduçáo no número de ovos por grama de fezes, no grupo tratado com raiz de Uncaria guianensis na concentração de $1,14 \mathrm{mg} / \mathrm{mL}$ e no grupo tratado quimicamente, onde obtiveram reduçáo estatisticamente significativa ( $\mathrm{p}<5 \%$ ), quando comparados aos demais grupos tratados, apresentando $69 \%$ e $66 \%$ respectivamente no percentual de redução. Em relaçáo ao número de larvas de terceiro estágio de nematóides gastrointestinais recuperadas de ovelhas, após o tratamento observaram que os grupos tratados com closantel, raiz de Uncaria guianensis na concentraçáo de $1,14 \mathrm{mg} / \mathrm{mL}$ e caule de Uncaria guianensis na concentraçáo de $1,25 \mathrm{mg} / \mathrm{mL}$ foram estatisticamente diferentes ( $\mathrm{p}<5 \%$ ) dos demais tratamentos, com redução de $68 \%$, 68\% e $86 \%$ respectivamente no número de larvas. Quanto ao hematócrito, os resultados permaneceram dentro dos padróes de referência para o Bioma Amazônia. Assim, concluímos que Uncaria guianensis possui atividade ovicida e larvicida sobre nematóides gastrointestinais em ovinos.

PALAVRAS-CHAVE: endoparasitas, fitoterapia, pequenos ruminantes

'Center of Biological and Natural Sciences, Federal University of Acre, Highway BR 364, 69920-900, Rio Branco - Acre (AC), Brazil.

2Department of Veterinary Medicine, Federal University of Rondônia - Rondônia (RO), Brazil.

${ }^{3}$ Department of Animal Healph, Embrapa Goat and Sheep/ CNPC, Road Sobral - Ceará (CE), Brazil.

${ }^{4}$ Department of Veterinary Medicine, Federal University of Campina Grande, - Paraíba (PB), Brazil.

*Correspondent author: sara.amorim@unir.br

Received: 08/04/2020. Accepted: 10/05/2020 


\section{INTRODUCTION}

Sheep and goat farming in Brazil represents one of the main sources of income for small and medium-sized rural producers, because they have a low labor cost and quick profitability. However, problems in health and food management have caused great economic losses (RIBEIRO et al., 2014). Endoparasites are a major obstacle to the rearing of small ruminants, since these parasites, especially Haemonchus sp., cause great losses because they cause severe anemia, a decrease in the production of meat and milk and, occasionally, death (CORLEY \& JARMON, 2012).

The conventional use of anthelmintics for control of endoparasitoses represents the main form of treatment; however, lack of knowledge about the epidemiology of parasitoses, inadequate use of these drugs (sub dosages) and management problems have led to the emergence of resistant strains (SINGH et al., 2014), as well as contamination of the environment and increase in the cost of production (ZARO et al., 2014).

New alternatives for control of endoparasitoses, such as use of medicinal plants with anthelmintic activity, have been used in the last years in an attempt to seek a more effective parasitic control. Moreover, they have low cost and non-polluting (ANDRADE et al., 2014). Brazil represents one of the largest sources of medicinal plants in the world, because it has the highest plant diversity (SANTOS et al., 2013). Several bioactive substances have been reported with anthelmintic properties such as condensed tannins (OLIVEIRA et al., 2011), flavonoids (FERNEX et al., 2012), saponins (EGRALE et al., 2007), steroids (CALA et al., 2012) and triterpenoids (MONTEIRO et al., 2011)

Phytotherapy in the control of verminoses is an alternative that can reduce the use of anthelmintics and prolong the life of the available chemical products. Many plants are traditionally known for their anthelmintic properties, but their efficacy needs to be proven scientifically (BORGES, 2014).

Among the several plants with pharmacological activity, Uncaria guianensis, popularly known as cat's claw, has been well studied for its curative effect on inflammatory problems (URBANIBIA et al., 2013) in bacterial diseases (CORREA et al., 2008), and tumor diseases (SANTOS et al.,2016, KAISER et al.,2016). According to reports from riverside communities in the Amazon, the plant also has an effect on gastrointestinal problems. Thus, the purpose of this work is to report, for the first time, the anthelmintic potential of Uncaria guianensis on eggs and larvae of gastrointestinal nematodes of sheep, and its effect on the hematocrit of naturally infected sheep, its phytochemical profile and toxicological analysis as an alternative in the control of parasitoses in the Western Amazon, Brazil.

\section{MATERIAL AND METHODS}

\section{Ethics Committee}

The experiment was approved by the Animal Testing Ethics Committee of the Federal University of Acre (Protocol number 69/2015).

\section{Collection of the botanical material}

Root and stem samples of Uncaria guianensis were collected at the Zoobotanical Park (PZ) of the Federal University of Acre - UFAC ( $9^{\circ} 58^{\prime} 29^{\prime \prime}$ "south and $\left.67^{\circ} 48^{\prime} 36^{\prime \prime} \mathrm{W}\right)$, identified and deposited in the herbarium of the Federal University of Acre, with exsicata number 6422 (Uncaria guianensis). The preparation of the exsicata, from collection to herborization, was described according to the methodology of Cartaxo et al. (2010).

\section{Preparation of the crude ethanolic extract}

Root and stem of Uncaria guianensis were collected and submitted to dehydration in a forced ventilation oven at $60^{\circ} \mathrm{C}$ for 24 hours, and then weighed and ground. The ethanolic extracts of the Uncaria guianensis of the root (EERUG) and the stem (EESUG) of Uncaria guianensis were prepared in the natural products laboratory of the Acre State Research Support Foundation (FUNTAC). Samples of Uncaria guianensis (root and stem) were extracted through a 70\% hydroalcoholic solution. After seven days of percolation, the vegetal material was filtered and submitted to evaporation to produce a viscous material. For efficient evaporation of the solvent, the material was placed in tared glass vials and then placed in a water bath; subsequently, it was lyophilized at a temperature of about $-30^{\circ} \mathrm{C}$ for 24 hours.

\section{In vitro tests}

In the In vitro tests, the degree of toxicity to Artemia salina was analyzed for determination of CL50. After the CL50 value was determined, an analysis was made of the ovicidal and larvicidal effect of the plant on gastrointestinal nematodes of sheep. Tests for phytochemical prospection were analyzed to check the presence of secondary metabolites with anthelmintic activity. The method of Araújo et al. (2010) was used to determine the degree of toxicity of the stem and root of Uncaria guianensis against Artemia salina. The extracts were diluted in a $1 \%$ dimethylsulfoxide solution (DMSO) at concentrations of 100, 500 and $1000 \mathrm{ug} / \mathrm{mL}$. Three control groups were used: CG1 (control group 1: 1\% DMSO); GC2 (Control group 2: solution isotonic saline) and GC3 (control group 3: $1 \% \mathrm{NaClO}$ ).

The values found with the mean number of dead Nauplius were submitted to statistical analysis, in which the lethal concentration was estimated at 50\% (CL50) of the larvae by the method of Probit analysis, and by the mathematical Trimmed Spearman-Karber method with a 95\% confidence interval.

After the CL50 of the extracts was calculated, ovicidal and larvicidal tests were performed through coprocultures using the methodology of Robert \& Sullivan (1950). $2 \mathrm{~mL}$ of the ethanolic extract was added at a concentration to be determined according to the toxicity test (quoted above) for fecal cultures naturally infected by gastrointestinal nematodes. In the negative control group, distilled water was used while 
closantel $7.5 \%$ was used in the positive control group. All treatments were performed in triplicates. The samples were placed in BOD greenhouses for control of temperature and humidity. After 7 days, the infective larvae (L3) were recovered and counted under an optical microscope.

To evaluate the efficiency of the extract on eggs and larvae in the different treatments, the formula described by CamurçaVasconcelos et al. (2007) was adapted:

\section{ET: initial L3 -L3 of the treated group/ initial L3}

Where: initial L3 corresponds to the estimate of the number of larvae in each coproculture

L3 of the treated group corresponds to the number of larvae recovered after 8 days of incubation in the different treatments.

In Phytochemical Prospecting, the ethanolic extracts were submitted to a series of phytochemical characterization reactions (reducing sugars, alkaloids, phenolic compounds, flavonoids, organic acids, anthraquinones, saponins, tannins and triterpenes and steroids) which were carried out in triplicates. The tests were based on chromatic and precipitation reactions as described by Simóes et al. (2001). The tests were carried out in the chemistry laboratory at UFAC.

\section{In vivo test}

30 sheep with no defined breed pattern with mean age between 1.5 and 2 years and mean body weight of $40 \mathrm{~kg}$ were randomly distributed into six groups of five animals, each group being treated differently with five replicates, as described below: Group 1 (G1): positive control, whose animals received closantel at $7.5 \%$ orally at the dose recommended by the manufacturer; Group 2 (G2): negative control, whose animals received no synthetic or natural vermifuge; G3): cat's claw root group (CL50) whose animals received $10 \mathrm{~mL}$ of the Uncaria guianensis extract, dissolved in water, at a concentration of $0.57 \mathrm{mg}$ / mL, orally, for six weeks, on a weekly basis; Group 4 (G4): cat's claw root group (duplicate dose), whose animals received $10 \mathrm{~mL}$ of the Uncaria guianensis extract, dissolved in water, at a concentration of $1.14 \mathrm{mg} / \mathrm{mL}$, orally, for six weeks, on a weekly basis; Group 5 (G5): Cat's claw stem (CL50) group, whose animals received $10 \mathrm{~mL}$ of the Uncaria guianensis extract, dissolved in water, at a concentration of $1.25 \mathrm{mg} / \mathrm{mL}$, for six weeks, on a weekly basis; Group 6 (G6): group of cat's claw stem (duplicate dose), whose animals received weekly $10 \mathrm{~mL}$ of the Uncaria guianensis extract, dissolved in water, at a concentration of $2.5 \mathrm{mg} / \mathrm{mL}$, orally, for six weeks.

Animals naturally infected with gastrointestinal nematodes were subjected to experimentation in confinement. The parasitic load of the animals at the beginning of the experiment was an average of 2000 eggs per gram of feces. The animals were evaluated through physical examination (PUGH, 2005), with analysis of conjunctival mucous membrane staining, body scoring, hair aspects, nasal secretion, cough, apathy and the presence of submandibular edema. Each sheep was identified with a flat wire collar and a numbered plate. Subsequently, they were distributed into six groups and housed in experimental units with an area of $4.0 \times 4.0 \mathrm{~m} 2$, on suspended slatted floor. The animals were fed maize silage, balanced concentrate ration (crushed corn, soybean meal, calcitic limestone, urea, calcium bicarbonate and mineral phosphorus), mineral salt at will (sheep pasture).

The experiment was carried out in a confinement center of Cordeiro da Amazônia, located on the highway AC 10, $\mathrm{km} 8$, in the rural area of Rio Branco, Acre. The predominant climate is hot humid, with an average annual temperature of $25^{\circ} \mathrm{C}$. Laboratory tests were carried out in the laboratory of parasitic diseases of domestic animals at the Federal University of Acre -UFAC, Rio Branco-Acre campus.

During the experiment, fecal material was collected directly from the rectal bulb on days $0,7,14,21,28$ and 35 to evaluate the action of the treatment during the entire biological cycle of gastrointestinal endoparasites. Blood samples were collected directly from the jugular vein of each animal on days 0, 14 and 28 (JAIN, 1993) for hematocrit (Ht) analysis. The samples were stored in sterile vacuum tubes containing EDTA (Ethylenediaminetetracetic-di-sodium) as an anticoagulant. After collection, stool and blood samples were kept in ice-styrofoam boxes until they were sent to the Laboratory of Animal Parasitology and Veterinary Clinical Pathology, respectively, from the Veterinary Medicine Teaching and Research Unit of the Federal University of Acre-UFAC.

\section{Statistical analysis}

The results of the OPG were analyzed after log transformation $(\mathrm{x}+1)$ and submitted to one-way analysis of variance (ANOVA) and Tukey's test at $5 \%$ of probability. For the analyses, the software BIOESTAT 5.0 (AYRES et al., 2007) was used. To determine the efficiency of the extracts of Uncaria guianensis on the reduction of eggs per gram of feces (REPGF), the methodology described by Coles et al. (1992) was used. REPGF: 1- [(EPGf / EPFi)] 100 Where: EPGf is the mean number of eggs per gram of feces at the end of treatment; EPG $i$ is the mean number of eggs per gram of feces at the beginning of the treatment. ANOVA was used, followed by Tukey's test. The results were processed in the statistical software SAS (version 9.1) with significance level of 5\%.

\section{RESULTS}

In the in vitro analysis, the toxicity tests with Artemia salina Leach identified that the ethanolic extracts of the root and the stem of cat's claw (Uncaria guianensis) are toxic in low concentrations with CL 50 equal to $0.57 \mathrm{mg} / \mathrm{mL}$ and $1.25 \mathrm{mg}$ $/ \mathrm{ml}$, respectively.

The number of third instar larvae (L3) of ovine gastrointestinal nematodes, obtained from coprocultures treated with 
the ethanolic extract of the root and the stem of cat's claw (Uncaria guianensis), showed a reduction of larvae $(\mathrm{p}<0.05 \%)$ of the treated groups when compared to the control group (Table 1). However, there was no difference with the values compared to the chemically treated group, which shows that the plant extracts were as efficient as closantel, one of the commonly used active principles.

Regarding the qualitative phytochemical test, Uncaria guianensis was positive for different chemical compounds (Table 2).

When evaluating the in vivo test, the percentage of reduction of the number of eggs per gram of feces (EPG) of naturally infected sheep was found only in the group treated with Uncaria guianensis at a concentration of 1.14 $\mathrm{mg} / \mathrm{mL}$ and in the treated chemically group, when compared to the other treated groups, with reduction percentage of $69 \%$ and $66 \%$, respectively. Animals from the stem-treated group of Uncaria guianenesis did not present satisfactory results. (Table 3).

As regards the number of third-stage larvae (L3) of gastrointestinal nematodes recovered from sheep after treatment with Uncaria guianensis, the groups treated with closantel, the root of Uncaria guianensis at the concentration of $1.14 \mathrm{mg}$ $/ \mathrm{mL}$ and the stem of Uncaria guianensis $(\mathrm{p}<0.05 \%)$, when compared to the other treatments, showed reductions in the number of larvae of $68 \%, 68 \%$ and $86 \%$, respectively (Table 4).

As for the hematocrit of treated animals, it was found that there was a significant reduction $(\mathrm{p}<0.05)$ in hematocrit values only in the groups treated with the root and the stem of Uncaria guianensis in the duplicate dose (Table 5).

\section{DISCUSSION}

According to the classification described by Meyer (1982), a product is considered to be toxic when it presents a lethal LC 50 concentration less than $1000 \mathrm{ug} / \mathrm{mL}$. In this work, the toxicity test with Artemia saline Leach served as an initial basis to investigate its biological activity on gastrointestinal nematodes of sheep. According to Amarante et al. (2011), the 50\% lethal concentration (CL50) is an indicator

Table 2. Phytochemical analysis of the ethanolic extract of the root of Uncaria guianensis (E.E.C.C.R.) and the ethanolic extract of the stem of Uncaria guianensis (E.E.C.C.S)

\begin{tabular}{l|c|c} 
& E.E.C.C.R. & E.E.C.C.S. \\
$\begin{array}{l}\text { Alkaloides (Bouchardat } \\
\text { reactive) }\end{array}$ & - & - \\
\hline Alkaloides ( & & - \\
Drangendorff reactive) & & \\
\hline $\begin{array}{l}\text { Alkaloides (Mayer } \\
\text { reactive) }\end{array}$ & - & - \\
\hline $\begin{array}{l}\text { Alckaloides ( Bertrand } \\
\text { reactive) }\end{array}$ & - & - \\
\hline Phenol and tannins & + & + \\
\hline Saponins & + & + \\
\hline Steroids and & - & - \\
triterpenoids & & \\
\hline Anthraquinones & - & - \\
\hline Reducing sugars & + & + \\
\hline Organic acids & - & - \\
\hline Flavonoids & - & + \\
\hline
\end{tabular}

+positive reaction, -negative reaction.

Table 1. Mean, standard deviation and percentages of reduction (PR\%) of third-stage larvae (L3) of gastrointestinal nematodes of sheep obtained from coprocultures treated with the ethanolic extract of the root and stem of cat's claw (Uncaria guianensis).

\begin{tabular}{|c|c|c|c|c|c|c|c|}
\hline & $\begin{array}{c}\text { Haemonchus } \\
\text { spp. }\end{array}$ & $\begin{array}{c}\text { Trichostrongylus } \\
\text { spp. }\end{array}$ & $\begin{array}{c}\text { Oesophagostomum } \\
\text { spp. }\end{array}$ & $\begin{array}{c}\text { Strongyloides } \\
\text { spp. }\end{array}$ & $\begin{array}{c}\text { Cooperia } \\
\text { spp. }\end{array}$ & $\begin{array}{l}\text { Ostertagia } \\
\text { spp. }\end{array}$ & $\begin{array}{l}\text { Total larvae } \\
\text { (L3) }\end{array}$ \\
\hline U & $\begin{array}{c}\text { Mean } \pm \text { SD } \\
(\text { PR \%) }\end{array}$ & $\begin{array}{c}\text { Mean } \pm \text { SD } \\
(\text { PR \%) }\end{array}$ & $\begin{array}{l}\text { Media } \pm \text { DP } \\
\text { (PR\%) }\end{array}$ & $\begin{array}{c}\text { Mean } \pm \text { SD } \\
(\text { PR \%) }\end{array}$ & $\begin{array}{c}\text { Mean } \pm \text { SD } \\
(\text { PR \%) }\end{array}$ & $\begin{array}{c}\text { Mean } \pm \text { SD } \\
\text { (PR \%) }\end{array}$ & $\begin{array}{c}\text { Mean } \pm \text { SD } \\
(\text { PR \%) }\end{array}$ \\
\hline G1 & $\begin{array}{c}82.00 \pm 17.06^{a} \\
(95 \%)\end{array}$ & $\begin{array}{c}61.00 \pm 32.91^{\mathrm{a}} \\
(76 \%)\end{array}$ & $\begin{array}{c}12.00 \pm 6.25^{a} \\
(78 \%)\end{array}$ & $\begin{array}{c}107.00 \pm 155.12^{\mathrm{b}} \\
(27 \%)\end{array}$ & $\begin{array}{c}0.00 \pm 0.00^{a} \\
(100 \%)\end{array}$ & $\begin{array}{c}3.00 \pm 3.46^{a} \\
86 \%)\end{array}$ & $\begin{array}{c}265 \pm 194.29^{1} \\
(87 \%)\end{array}$ \\
\hline G2 & $\begin{array}{c}59.67 \pm 40.81^{a} \\
(83 \%)\end{array}$ & $\begin{array}{c}107.33 \pm 27.03^{b} \\
(57 \%)\end{array}$ & $\begin{array}{c}41.67 \pm 22.7^{b} \\
(22 \%)\end{array}$ & $\begin{array}{c}327.67 \pm 233.26^{c} \\
(0 \%)\end{array}$ & $\begin{array}{c}9.67 \pm 8.62 \mathrm{c} \\
(17 \%)\end{array}$ & $\begin{array}{c}2.67 \pm 2.09^{a} \\
(86 \%)\end{array}$ & $\begin{array}{c}748.67 \pm 314.05^{2} \\
(63 \%)\end{array}$ \\
\hline G3 & $\begin{array}{c}12.67 \pm 15.31^{\mathrm{a}} \\
(99 \%)\end{array}$ & $\begin{array}{c}0.33 \pm 0.58^{\mathrm{a}} \\
(100 \%)\end{array}$ & $\begin{array}{c}2.67 \pm 2.08^{a} \\
(95 \%)\end{array}$ & $\begin{array}{c}2.67 \pm 4.62^{\mathrm{a}} \\
(98 \%)\end{array}$ & $\begin{array}{c}0.00 \pm 0.00^{a} \\
(100 \%)\end{array}$ & $\begin{array}{c}0.67 \pm 0.58^{a} \\
(97 \%)\end{array}$ & $\begin{array}{c}19.00 \pm 22.72^{1} \\
(99 \%)\end{array}$ \\
\hline G4 & $\begin{array}{c}6.67 \pm 4.73^{\mathrm{a}} \\
(100 \%)\end{array}$ & $\begin{array}{c}0.33 \pm 0.58^{\mathrm{a}} \\
(100 \%)\end{array}$ & $\begin{array}{l}0.67 \pm 1.16^{a} \\
(99 \%)\end{array}$ & $\begin{array}{c}1.00 \pm 1.00^{\mathrm{a}} \\
(99 \%)\end{array}$ & $\begin{array}{c}0.00 \pm 0.00^{a} \\
(100 \%)\end{array}$ & $\begin{array}{c}0 .(00 \pm 0.00)^{a} \\
(100 \%)\end{array}$ & $\begin{array}{c}8.67 \pm 7.23^{1} \\
(100 \%)\end{array}$ \\
\hline G5 & $\begin{array}{c}45.33 \pm 55.95^{\mathrm{a}} \\
(97 \%)\end{array}$ & $\begin{array}{c}16.00 \pm 17.58^{\mathrm{a}} \\
(94 \%)\end{array}$ & $\begin{array}{c}4.33 \pm 4.51^{\mathrm{a}} \\
(93 \%)\end{array}$ & $\begin{array}{c}8.33 \pm 7.02^{\mathrm{a}} \\
(94 \%)\end{array}$ & $\begin{array}{c}0.00 \pm 0.00^{a} \\
(100 \%)\end{array}$ & $\begin{array}{c}0.33 \pm 0.58^{a} \\
(99 \%)\end{array}$ & $\begin{array}{c}74.33 \pm 80.58^{1} \\
(99 \%)\end{array}$ \\
\hline G6 & $\begin{array}{c}9.33 \pm 6.66^{a} \\
(99 \%)\end{array}$ & $\begin{array}{l}0.00 \pm 0.00^{a} \\
(100 \%)\end{array}$ & $\begin{array}{c}1.33 \pm 0.58^{\mathrm{a}} \\
(98 \%)\end{array}$ & $\begin{array}{c}3.00 \pm 1.00^{a} \\
(98 \%)\end{array}$ & $\begin{array}{c}0.00 \pm 0.00^{a} \\
(100 \%)\end{array}$ & $\begin{array}{c}0.33 \pm 0.58^{a} \\
(85 \%)\end{array}$ & $\begin{array}{c}14.00 \pm 0.681 \\
(99 \%)\end{array}$ \\
\hline
\end{tabular}

Values followed by different letters in the same column differ statistically $(p=0.05)$ by Tukey's test for independent samples. $G 1$ : Positive control (closantel 7.5\%); G4: Cat's claw root (Duplicate dose: 1.14mg / mL), G5: Cat's claw stem LC 50\% (0.57mg / mL); 1.25mg / mL), G6: cat's claw stem (duplicate dose: $2.5 \mathrm{mg} / \mathrm{mL}$ ). 
Table 3. Arithmetic mean, re-transformed $\log (x+1)$, standard deviation and percentage of reduction of number of eggs per gram of feces (EPG) of naturally infected sheep treated with the ethanolic extract of the root and the stem of Cat's claw (Uncaria guianensis).

\begin{tabular}{|c|c|c|c|c|c|c|c|}
\hline Group & Day zero/OPG & Day 07/OPG & Day 14 /OPG & Day 21 /OPG & Day 28/OPG & Day 35 OPG & RCOF\% \\
\hline G1 & $\begin{array}{c}10560 \\
( \pm 5125.9)^{a}\end{array}$ & $\begin{array}{c}2520 \\
( \pm 2021.3)^{b}\end{array}$ & $\begin{array}{c}3520 \\
( \pm 2295.6)^{b}\end{array}$ & $\begin{array}{c}4780 \\
( \pm 4401.5)^{b}\end{array}$ & $\begin{array}{c}4140 \\
( \pm 2897.9)^{b}\end{array}$ & $\begin{array}{c}3620 \\
( \pm 1925)^{b}\end{array}$ & $66 \%$ \\
\hline G2 & $\begin{array}{c}640 \\
( \pm 162.5)^{a}\end{array}$ & $\begin{array}{c}1320 \\
( \pm 1002.8)^{b}\end{array}$ & $\begin{array}{c}640 \\
( \pm 344.1)^{b}\end{array}$ & $\begin{array}{c}460 \\
( \pm 287.1)^{b}\end{array}$ & $\begin{array}{c}540 \\
( \pm 102)^{b}\end{array}$ & $\begin{array}{c}580 \\
( \pm 116.6)^{b}\end{array}$ & $9 \%$ \\
\hline G3 & $\begin{array}{c}2320 \\
( \pm 1522.4)^{a}\end{array}$ & $\begin{array}{c}3800 \\
( \pm 3507.7)^{a}\end{array}$ & $\begin{array}{c}1420 \\
( \pm 1146.1)^{a}\end{array}$ & $\begin{array}{c}1560 \\
( \pm 1645.1)^{a}\end{array}$ & $\begin{array}{c}2520 \\
( \pm 2679.9)^{a}\end{array}$ & $\begin{array}{c}1800 \\
( \pm 1621.1)^{a}\end{array}$ & $22 \%$ \\
\hline G4 & $\begin{array}{c}3220 \\
( \pm 1502.5)^{a}\end{array}$ & $\begin{array}{c}3760 \\
( \pm 2327.8)^{a}\end{array}$ & $\begin{array}{c}460 \\
( \pm 591.9)^{\mathrm{b}}\end{array}$ & $\begin{array}{c}1900 \\
( \pm 1823.2)^{a}\end{array}$ & $\begin{array}{c}2180 \\
( \pm 1702.2)^{a}\end{array}$ & $\begin{array}{c}1000 \\
( \pm 914.3)^{b}\end{array}$ & $69 \%$ \\
\hline G5 & $\begin{array}{c}3200 \\
( \pm 2155)^{a}\end{array}$ & $\begin{array}{c}1280 \\
( \pm 1036.1)^{a}\end{array}$ & $\begin{array}{c}2480 \\
( \pm 3357.6)^{a}\end{array}$ & $\begin{array}{c}5180 \\
( \pm 3680.4)^{a}\end{array}$ & $\begin{array}{c}5940 \\
( \pm 6950.9)^{a}\end{array}$ & $\begin{array}{c}5940 \\
( \pm 6950.9)^{a}\end{array}$ & $-86 \%$ \\
\hline G6 & $\begin{array}{c}4420 \\
( \pm 3861.3)^{a}\end{array}$ & $\begin{array}{c}5520 \\
( \pm 4823.9)^{a}\end{array}$ & $\begin{array}{c}1900 \\
( \pm 1554.3)^{a}\end{array}$ & $\begin{array}{c}7720 \\
( \pm 9285.98)^{a}\end{array}$ & $\begin{array}{c}10660 \\
(9271.2)^{a}\end{array}$ & $\begin{array}{c}6900 \\
( \pm 4975.1)^{\mathrm{a}}\end{array}$ & $-56 \%$ \\
\hline
\end{tabular}

Values followed by different letters in the rows differ statistically $(\mathrm{p0}, 05)$ by Tukey's test for independent samples. $\mathrm{G} 1$ : positive control, Closantel; $\mathrm{G} 2$ : negative control; G3: cat's claw root $=0.57 \mathrm{mg} / \mathrm{mL}$. G4: cat's claw root $1.14 \mathrm{mg} / \mathrm{mL}$ (group with duplicate dose), G5: cat's claw stem $=1.25 \mathrm{mg} /$ $\mathrm{mL}, \mathrm{G6}$ : cat's claw stem $=2.5 \mathrm{mg} / \mathrm{mL}$.

Table 4. Mean, standard deviation (SD) and percentage of reduction (\%) of third stage larvae (L3) of gastrointestinal nematodes recovered from Santa Inês crossbred sheep, after treatment with the ethanolic extract of the root and stem of cat's claw (Uncaria guianensis).

\begin{tabular}{|c|c|c|c|c|c|c|c|c|c|c|c|c|}
\hline Genu: & Control + & $\%$ & Control - & $\%$ & C.C.R.1 & $\%$ & C.C.R. 2 & $\%$ & C.C.S. 1 & $\%$ & C.C.S. 2. & $\%$ \\
\hline Haemonchus spp. & $\begin{array}{c}272.00 \\
( \pm 225.28)^{a}\end{array}$ & 82 & $\begin{array}{c}816.667 \\
( \pm 340.34)^{\mathrm{a}}\end{array}$ & 46 & $\begin{array}{c}474.00 \\
( \pm 96.67)^{\mathrm{a}}\end{array}$ & 69 & $\begin{array}{c}827.33 \\
( \pm 445.06)^{\mathrm{a}}\end{array}$ & 45 & $\begin{array}{c}4595.67 \\
( \pm 1784.95)^{a}\end{array}$ & 0 & $\begin{array}{c}89.00 \\
( \pm 60.36)^{a}\end{array}$ & 94 \\
\hline $\begin{array}{l}\text { Trichostrongylus } \\
\text { spp. }\end{array}$ & $\begin{array}{c}77.67 \\
( \pm 56.87)^{b}\end{array}$ & 69 & $\begin{array}{l}299.000 \\
( \pm 53.70)^{b}\end{array}$ & 20 & $\begin{array}{c}90.33 \\
( \pm 69.14)^{\mathrm{a}}\end{array}$ & 64 & $\begin{array}{c}343.00 \\
( \pm 231.62)^{b}\end{array}$ & 0 & $\begin{array}{c}321.00 \\
( \pm 56.93)^{\mathrm{a}}\end{array}$ & 0 & $\begin{array}{c}115.00 \\
( \pm 107.50)^{b}\end{array}$ & 54 \\
\hline $\begin{array}{l}\text { Oesophagostomum } \\
\text { spp. }\end{array}$ & $\begin{array}{c}101.67 \\
( \pm 72.92)^{c}\end{array}$ & 0 & $\begin{array}{c}26.333 \\
( \pm 14.15)^{\mathrm{a}}\end{array}$ & 52 & $\begin{array}{c}6.67( \pm 4.62) \\
b\end{array}$ & 88 & $\begin{array}{c}13.66 \\
( \pm 15.822)\end{array}$ & 75 & $\begin{array}{c}14.667 \\
( \pm 9.61)^{b}\end{array}$ & 33 & $\begin{array}{c}41.67 \\
( \pm 42.37)^{c}\end{array}$ & 33 \\
\hline Strongyloides spp. & $\begin{array}{c}182.33 \\
( \pm 195.99)^{c}\end{array}$ & 0 & $\begin{array}{l}387.667 \\
( \pm 58.80)^{c}\end{array}$ & 0 & --------* & & $--^{*}$ & & $\begin{array}{c}1842.33 \\
( \pm 1722.82)^{a}\end{array}$ & 0 & $\begin{array}{c}38.00 \\
( \pm 54.03)^{\mathrm{a}}\end{array}$ & 74 \\
\hline Cooperia spp. & $0.00( \pm 0.00)^{a}$ & 100 & $\begin{array}{c}9.000 \\
( \pm 1.00)^{c}\end{array}$ & 25 & $\begin{array}{c}0.00( \pm 0.00) \\
b\end{array}$ & 100 & $0.00( \pm 0.00)^{c}$ & 100 & $\begin{array}{c}132.33 \\
( \pm 206.71)^{\mathrm{a}}\end{array}$ & 0 & $\begin{array}{c}0.00 \\
( \pm 0.00)^{\mathrm{a}}\end{array}$ & 100 \\
\hline Ostertagia spp. & $4.33( \pm 4.04)$ & 82 & $\begin{array}{r}17.000 \\
( \pm 5.29)^{c}\end{array}$ & 23 & $\begin{array}{c}68.00 \\
( \pm 54.51)^{c}\end{array}$ & 0 & $\begin{array}{c}193.33 \\
( \pm 173.52)^{b}\end{array}$ & 0 & $\begin{array}{c}190.33 \\
( \pm 35.16)^{\mathrm{a}}\end{array}$ & 0 & $\begin{array}{c}2.67 \\
( \pm 3.79)^{\mathrm{a}}\end{array}$ & 88 \\
\hline Total & $\begin{array}{c}638.00 \\
( \pm 536.05)^{1}\end{array}$ & 68 & $\begin{array}{r}1555.667 \\
( \pm 345.63)^{2}\end{array}$ & 22 & $\begin{array}{c}639.00 \\
( \pm 159.93)^{1}\end{array}$ & 68 & $\begin{array}{c}1377.33 \\
( \pm 802.34) 2\end{array}$ & 31 & $\begin{array}{c}7096.33 \\
( \pm 3092.1)^{3}\end{array}$ & 0 & $\begin{array}{c}286.33 \\
( \pm 263.77)^{1}\end{array}$ & 86 \\
\hline
\end{tabular}

Values followed by different letters in the same column and number per row differ statistically $(p=0.05)$ by Tukey's test for independent samples. Positive control: Closantel 7.5\%; negative control: distilled water; C.C.R.1: Cat's claw root, duplicate dose: 1.14mg / mL C.C.R.2: Cat's claw root at $50 \%$ lethal concentration: $0.57 \mathrm{mg} / \mathrm{mL}$; C.C.S. 1 : cat's claw stem $2.5 \mathrm{mg} / \mathrm{mL}$ (duplicate dose group); C.C.S. 2.: Cat's claw root at $50 \%$ lethal concentration: $1.25 \mathrm{mg} / \mathrm{mL}$. ${ }^{*}$ Countless numbers of strongyloides.

Table 5. Mean percentage values of the Hematocrit of sheep naturally infected by gastrointestinal nematodes treated with the ethanolic extract of the root and the stem of cat's claw (Uncaria guianensis)

\begin{tabular}{l|c|c|c|c|c|c} 
Day/tratament & $\mathbf{G 1}$ & $\mathbf{G 2}$ & $\mathbf{G 3}$ & $\mathbf{G 4}$ & $\mathbf{G 5}$ & $\mathbf{G 6}$ \\
\hline Day zero & $19.27( \pm 9.1)^{\mathrm{a}}$ & $36.3( \pm 2.4)^{\mathrm{a}}$ & $30.45( \pm 6.52)^{\mathrm{a}}$ & $30.8( \pm 4.2)^{\mathrm{a}}$ & $28.6( \pm 8.0)^{\mathrm{a}}$ & $28.1( \pm 4.1)^{\mathrm{ab}}$ \\
\hline 14 & $25( \pm 8.0)^{\mathrm{a}}$ & $38.2( \pm 4.2)^{\mathrm{ab}}$ & $33.93( \pm 7.59)^{\mathrm{a}}$ & $31.4( \pm 3.2)^{\mathrm{a}}$ & $29.04( \pm 9.9)^{\mathrm{a}}$ & $30.1( \pm 3.9)^{\mathrm{a}}$ \\
\hline 28 & $20.6( \pm 6.2)^{\mathrm{a}}$ & $32.2( \pm 1.6)^{\mathrm{b}}$ & $24.58( \pm 5.93)^{\mathrm{a}}$ & $22.4( \pm 2.4)^{\mathrm{b}}$ & $20.77( \pm 10.3)^{\mathrm{a}}$ & $20.4( \pm 6.1)^{\mathrm{b}}$ \\
\hline
\end{tabular}

Values followed by different letters per column differ statistically $(\mathrm{p0}, 05)$ by Tukey's test for independent samples. G1: positive control, Closantel; G2: negative control; G3: cat's claw root $=0.57 \mathrm{mg} / \mathrm{mL}$. G4: cat's claw root $1.14 \mathrm{mg} / \mathrm{mL}$ (group with duplicate dose), G5: cat's claw stem: $1.25 \mathrm{mg} / \mathrm{mL}, \mathrm{G6}$ : cat's claw stem: $2.5 \mathrm{mg} / \mathrm{mL}$ (duplicate dose). 
that there are bioactive metabolites that can be used for an anthelmintic effect.

The results in vitro demonstrate the larvicidal action of Uncaria guianensis on gastrointestinal nematode larvae, especially the genus Haemonchus spp, a species responsible for the highest losses in animal production, as a result of its high pathogenicity and anthelmintic resistance (ANDRADE et al., 2014). According to the results, the groups treated with Uncaria guianensis were efficient in their larvicidal activity with a reduction percentage of almost $100 \%$ compared to the control group, which was $87 \%$.

According to the norms established by the Ministry of Agriculture, Livestock and Supply (MAPA), ordinance no. 48/1997 (BRAZIL,2011), Uncaria guianensis was highly effective against eggs and larvae of gastrointestinal nematodes of sheep in the Western Amazon, while the chemically-treated group was moderately effective.

Secondary metabolites are used in medicine because of their great variability in biological activity. Several studies have confirmed that phenolic compounds are involved in antioxidant (SILVA et al., 2010), anti-inflammatory (SINGH et al, 2003), antimicrobial (SIMÓES ,2007), and anthelmintic (OLIVEIRA et al., 2011) activities. Tannins act direct on the natural cycle of helminths, as well as inhibit rumen degradation of proteins, thus making the animals more resistant to diseases (KETZIS et al., 2013). The use of polyvinyl polypyrrolidone (PVPP) for confirmation of the antihelmintic activity of condensed tannins, has suggested that other bioactive metabolites may also be acting synergistically, as is the case of saponins and flavonoids (MACEDO et al., 2011). Therefore, the phytochemical tests in the present study showd that the ethanolic crude extracts from Uncaria guianensis have chemical metabolites that may be responsible for anthelmintic activity.

The in vivo results show that the root of Uncaria guianensis, at a concentration of $1.14 \mathrm{mg} / \mathrm{mL}$, presented anthelmintic activity because there was a significant reduction in its ovicidal and larvicidal activity, that is, in some way, the root extract of Uncaria guianensis interfered with the reproduction of nematodes by reducing their parasitic load and hindering the development of third stage larvae, thereby reducing the contamination of pastures. Although the stem of Uncaria guianensis did not show a reduction in egg count per gram of feces (EPG), it showed negative results $(-86 \%)$, that is, the animals continued with high parasite load levels, but the number of third-stage (L3) larvae of gastrointestinal nematodes was significantly reduced after treatment at the concentration of $1.25 \mathrm{mg} / \mathrm{mL}$, with an $86 \%$ percent reduction in larvae. This explains why the ethanolic extract of the stem of cat's claw did not interfere in the reproduction of nematodes, which continued after oviposture, although the viability of these eggs was impaired. Thus, somehow, there was a direct interference on larval development.
This anthelmintic response of Uncaria guianeneis may be associated with the presence of secondary metabolites in the plant, and the root possibly has a higher amount of these metabolites than the stem, because the root has been more efficient in its anthelmintic activity. Testing with different parts of the plant should be analyzed, since active principles can be found in different parts of the plant. In addition to this choice, the preparation of a plant for medicinal purposes is essential in order for bioactive metabolites to exert their pharmacological effect, and for their chemical properties not to be modified (PINTO et al., 2000)

The biological effects of medicinal plants are mainly attributed to the presence of secondary metabolites. The investigation of chemical components is the first step in the development of new anthelmintic drugs (MACEDO et al., 2011).

The results found in the present work may be linked to the presence of condensed tannins, since this chemical component has the ability to bind to parasite protein complexes (ALONSO DIAZ, 2011) because it affects the biology of nematodes, interfering with motility, cuticule elimination, egg hatching and larval development (FERNEX et al., 2012). They thus affect the reproductive function of nematodes by reducing the number of eggs in oviposture (MACEDO et al., 2012), reducing the number of infective larvae in the environment or improving the animals' immune response to parasites (HOSTE et al., 2006; OLIVEIRA et al., 2011)

Other secondary metabolites such as triterpenoids, sesquiterpene lactones, saponins, flavonoids and steroids have been implicated in anthelmintic activity of small ruminants. (MARIE-MAGDELEINE et al., 2009; MORAIS COSTA et al., 2015; MORAIS COSTA et al., 2014; NOGUEIRA et al., 2012).

Other plant species of the Rubiaceae family have also been reported to have anthelmintic activity. Onyeyili et al. (2001), when evaluating the aqueous extract of the stem of Nauclea latifolia on ovine nematodes, found a significant reduction $(93 \%)$ in the number of eggs in the feces of infected animals. Brito et al. (2009) found in vitro anthelmintic activity of the aqueous and ethanolic extracts of Morina citrifolia on chicken nematodes (Ascaridia galli) with $50 \%$ and $77 \%$ efficiency of the product. Wabo Pone et al. (2010) also found nematicidal properties in in vitro tests with the extract of Canthium mannii in different stages of life of Heligmosomoides polygyrus (Nematoda, Heligmosomatidae) in West Cameroon (Central Africa). In vivo tests with the extract of Canthium mannii in rodents parasitized by Heligmosomoides polygyrus showed that this compound is effective in reducing both faecal egg counts and total worm counts by $75 \%$ and $84 \%$, respectively (WABO PONE et al., 2009).

Antiparasitic activity have also been reported for plants of the Rubiaceae family such as Mitracarpus frigidus against Schistosoma mansoni (FABRI et al., 2014), Craterispermum laurinum and Morinda lucida against Onchocerca ochengi (SAMJE 
et al., 2014), Plasmodium falciparum (KOUMAGLO et al. 1992) Trypanosoma brucei (KWOFIE et al., 2016; ASUZU et al., 1990), and Leishmania (AMOA BOSOMPEN et al., 2016).

The of hematocrit results show that the groups treated with Uncaria guianensis did not influence the adult form of the parasite, since they continued with their intense hematophagy. Despite the reduction in the hematocrit, hematocrit reference values for sheep were within the reference values in the Amazonian biome, i.e., - $20.7-38.7 \%$ for sheep of 7-24 months (LIMA et al., 2015). The animals did not present signs of anemia. Therefore, the results found in this study are within the reference values for sheep raised in the Amazon biome.

Studies have shown that the genre Uncaria protects human erythrocytes from damaging effects against catalase. Catalase is an enzymatic protein found in aerobic cells, primarily in the liver, kidney and red blood cells; it is used as a useful marker for these (protective) organs. In erythrocytes, catalase is found as a soluble marker protecting against peroxidation of hemoglobin (AEBI ,1984). Bors et al. (2011) found that Uncaria tomentosa did not induce hemolysis of the heritrichocytes nor lipid peroxidation, and there was no interference with the structures and function of hemoglobin, nor oxidation or denaturation. Phenolic compounds may be present in this protective action against hemolysis and in the oxidation process.
Swwalsky et al. (2008) also corroborate that the effects mentioned above are due to the presence of polyphenols in the plant. Polyphenols have the ability to clear free radicals and inhibit lipid peroxidation (PROCHAZKOVA et al., 2011). Similar results were also found by Bukowska et al. (2012).

This work is the first to report the anti-helminth activity of Uncaria guianensis on gastrointestinal nematodes of sheep, but several studies cite other pharmacological activities of this species or of the genus Uncaria, e.g., anti-inflammatory and anti-tumoral (SANTOS et al., 2016; KAISER et al., 2016; URBANIBIA et al., 2013; CAON et al.,2014), anti-allergic (CARVALHO et al., 2006), antimicrobial (CORREIA et al., 2008) activity. These authors confirm the presence of chemical metabolites that may be associated with these therapeutic effects, such as oxindolic alkaloids, flavonoids and polyphenols, which may act alone or synergistically.

\section{CONCLUSION}

The results found in this study confirm that Uncaria guianensis has ovicidal and larvicidal activity on gastrointestinal nematodes of sheep in the Western Amazon, and that the presence of bioactive chemical substances such as condensed tannins can be a determining factor for such activity, thus resulting in a good alternative for control of nematodes.

\section{REFERENCES}

AEBI, H.1984. Catalase in vitro. In: Packer, L. (Ed.) Methods in Enzymology, vol.105. Academic Press, Orlando, pp. 121-126.

ALONSO-DÍAZ, M.A. et al. 201 1.Comparing the sensitivity of two in vitro assays to evaluate the anthelmintic activity of tropical tannin rich plant extracts against Haemonchus contortus. Vet. Parasitol. 181, 360-364.

ANDRADE, F. D. et al. 2014. Ação anti-helmíntica do extrato hidroalcóolico da raiz da Tarenaya spinosa (Jacq.) Raf. no controle de Haemonchus contortus em ovinos.Pesq. Vet. Bras. 34(10):942-946.

AMARANTE, C.B. et al. 2011 .Estudo fitoquímico biomonitorado pelos ensaios de toxicidade frente à Artemia salina e de atividade antiplasmódica do caule de aninga (Montrichardia linifera). Acta Amazonica 41:431-434.

AMOA-BOSOMPEM, $M$ et al. 2016. In vitro anti-Leishmania activity of tetracyclic iridoids from Morinda lucida, Benth. Trop Med Health. Aug (5)44:25,doi: 10.1186/ s41 182-016-0026-5

ARAÚJO, M.G.F., CUNHA W.R. \& VENEZIANI R.C.S.2010. Preliminary phytochemical study and toxicological bioassay against larvae of Artemia salina Leach. of extract obtained from fruits of Solanum lycocarpum A. St.-Hill. (Solana-ceae). Revta Ciênc. Farm. Basic Apl. 31: 205-209.

ASUZU, I.U. \& CHINEME, C.N. 1990.Effects of Morinda lucida leaf extract on Trypanosoma brucei brucei infection in mice. $J$ Ethnopharmacol , 30(3):307-313.

AYRES, M. et al.2007. BIOESTAT: statistical applications in the areas of bio-medical sciences. Ong Mamiraua. Belém, PA.

BORS, M. et al. 2011 .Protective activity of Uncaria tomentosa extracts in human erythrocytes in oxidative stress induced by 2,4-dichlorophenol (2,4-DCP) and catechol. Food Chem Toxicol. 49 (9): $2202-11$, doi: $10.1016 /$ j.fct.2011.06.013.

BRAZIL. 2011 . Ministry of Agriculture, Livestock and Supply. Ministerial Order n. 48 of May 12, 1997. Approves the Technical Regulation for the licensing and / or renewal of veterinary antiparasite products license. Published in the Federal Official Gazette of May 16, 1997, Section 1, Page 10165.

BRITO, D.R. et al. 2009.Antishelmintic activity of aqueous and ethanolic extracts of Morinda citrifolia fruit in galli Ascaridia.Vet Rev Bras Parasitol. Oct-Dec; 18 (4): 32-6.

BUKOWSKA, B. et al.2012.Uncaria tomentosa extracts protect human erythrocyte catalase against damage induced by 2,4-D-Na 
and its metabolites. Food and Chemical Toxicology, v.50:21132127, doi: $10.1016 /$ j.fct.2012.02.099.

CALA, A.A. et al. 2012. In vitro anthelmintic effect os Melia azadarach L. and Trichilia claussenii C. against sheep gastrointestinal nematodes. Experimental Parasitology,130:98-102.

CAMURÇA-VASCONCELOS, A.L.F. et al. 2007.Anthelmintic activity of Croton zehntneri and Lippia sidoides essential oils. Vet. Parasitol. 148:288-294.

CAON, T. et al. 2014. Antimutagenic and antiherpetic activities of different preparationsfrom Uncaria tomentosa (cat's claw). Food and Chemical Toxicology, DOI:10.1016/j.fct.2014.01.013.

CARTAXO, S.L.; SOUZA, M.M.A. \& ALBUQUERQUE, U.P. 2010. Medicinal plants with bioprospecting potential used in semi-arid Northeastern Brazil. J. Ethno-pharmacol. 131: 326-342.

CARVALHO M.V.L. et al. 2006.Investigations on the antiinflammatory and anti-allergic activities of the leaves of Uncaria guianensis (Aublet) J. F. Gmelin. Inflammopharmacology 14 :48-56.

COLES, G.C.et al. 1992. World Association for the Advancement of Veterinary Parasitology (WAAVP) methods for the detection of anthelmintic resistance in nematodes of veterinary importance. Vet. Parasitol. 44:35-44.

CORLEY, M.M. \& JARMON, A.A. 2012 .Interleukin 13 as a Biomarker for Parasite Resistance in Goats Naturally Exposed to Haemonchus contortus. Journal of Agriculture Science, 4:31-40.

CORREIA, A.F. et al. 2008.Amazonian plant crude extract screening for activity against multidrug-resistant bacteria. Eur Rev. Med. Pharmacol Sci, 12(6):369-80.

EGUALE, T. et al. 2007. In vitro and in vivo anthelmintic activity of crude extracts of Coriandrum sativum against Haemonchus contortus. J. Ethnopharmacol., 1 10, pp. 428-433

FABRI, R.L. et al. 2014.Chromatographic analysis of fingerprints and effects of medication frigidus Mitracarpus plant species in adult Schistosoma mansoni. Biomed Res Int. 2014: 941.318. doi: $10,1155 / 2014 / 941318$

FERNEX, E.V.S. et al. 2012. In vitro anthelmintic activity of five tropical legumes on the exshethment and motility of Haemonchus contortus infective larvae. Experimental Parasitology, v. 131 , p.413-418.

HOSTE, H. et al. 2006.The effects of tannin-rich plants on parasitic nematodes in ruminants .Trends Parasitol., 22 pp. 25-261

JAIN N.C. 1993. Essentials of Veterinary Hematology. Lea and Febiger, Phila-delphia. 417p.

LIMA, M.B. et al. 2015. Blood reference ranges and the influence of age and sex on hematological and biochemical parameters of Santa Inês sheep sheep reared in the Eastern Amazon.Acta Amazonica, vol. 45 (3) 2015: 317-322.

KAISER, S. et al. 2016.Genotoxicity and cytotoxicity of oxindole alkaloids of Uncaria tomentosa (cat's claw): Importance chemotipo.J.Ethnopharmacol. 189: 90-8. doi: 10.1016 / j.jep.2016.05.026.

KOUMAGLO, K.et al.1992.Effects of three compounds extracted from Morinda lucida on Plasmodium falciparum. Planta Med, 58(6):533-534.
KWOFIE, K.D et al. 2016.Antitrypanosomal Activities and Mechanisms of Action of Novel Tetracyclic Iridoids from Morinda lucida Benth.Antimicrob Agents Chemother. May 23;60(6):3283-90, doi: 10.1128/AAC.01916-15.

MACEDO, I.T.F. et al. 2012. In vitro activity of Lantana camara, Alpinia zerumbet, Mentha villosa and Targetes minuta decotions on Haemonchs contortus eggs and larvae. Veterinary Parasitology, p. 504-509, http://dx.doi.org/10.1016/j.vetpar.2012.07.001.

MARIE-MAGDELEINE, C. et al. 2009. In vitro effects of Cucurbita moschata seed extracts on Haemonchus contortus Vet. Parasitol,16 pp. 99-105.

MEYER, B.N. et al. 1982.Brine shrimp: a convenient general bioassay for active plant constituents. J. Med. Plant Res. 45:31-34.

MONTEIRO, M. V. B. et al. 2011 . Anthelmintic activity of Jatropha curcas L. seeds on Haemonchus contortus. Veterinary Parasitology. 182, 259- 263.

MORAIS-COSTA, F. et al. 2015.Plants of the Cerrado naturally selected by grazing sheep may have potential for inhibiting development of Haemonchus contortus larva. Trop Anim Health Prod,(47): 1321-1328.

MORAIS-COSTA, F. et al.2014.Anthelmintics clinical pharmacology, uses in veterinary medicineand efficacy. In: Anthelmintics Clinical Pharmacology, Uses in Veterinary Medicine and Efficacy. Willian Quick (ed), Nova Science Publishers: New York, EUA, p. 89-108.

NOGUEIRA, F.A. et al. 2012 .In vitro and in vivo efficacyof aqueous extract of Caryocar brasiliense Camb. to control gastrointestinal nematodes in sheep. Parasitology Research, 111:325-330.

OLIVEIRA, L.M.B. et al. 2011 . Taniniferous plants and the control of gastrointestinal nematodes of small ruminants. Rural Science, Santa Maria, v.41, n.11, p.1967-1974.

ONYEYILI, P.A. et al.2001.Anti-helminth activity of the crude aqueous extract of Nauclea latifolia stem bark against sheep nematodes. Phytotherapy. 72 (1): 12-21.

PINTO, J.E.B.P.; SANTIAGO, E.J.A. \& LAMEIRA, O.A. 2000. Compendium of medicinal plants. Lavras: PROEX / UFLA, 74p. (Extension Bulletin, 70).

PROCHAZKOVA, D.; BOUŠOVA, I. \& WILHELMOVA I. 2011. Antioxidant and prooxidantproperties of flavonoids. Fitoterapia, 82:513-523.

PUGH, D. G. 2005. Sheep and goat's clinic. São Paulo: Roca, $513 p$.

RIBEIRO, A.R.C. et al. 2014. Study of the antihelminthic activity of the ethanolic extract of Jatropha mollissima (Pohl) Baill. (Euphorbiaceae) under Haemonchus contortus in sheep in the semi-arid Paraibano. Pesq. Vet. Bras. 34 (11): 1051-1055.

ROBERTS, F.H.S. \& O'SULLIVAN, J.P.1950. Methods for egg counts and larval cultures for strongylesinfsting the gastrointestinal tract of cattle.Aust. J. Agric. Res. 1:99-102.

SAMJE, M. et al.2014.The activities ochengi anti-Onchocerca in vitro extracts and chromatographic fractions craterispermum laurinum and Morinda lucida.The official journal of the International Society of Complementary Medicine (ISCMR), DOI: 10,1186 / 1472-6882-14-325 
SANTOS, A.C.B. et al. 2013. Ethnobotanical, chemical and pharmacological survey of Apocynaceae species. occurring in Brazil. Revta Bras. Plant. Med. 15 (3): 442-458.

SANTOS, K. F. et al. 2016 .Uncaria tomentosa Extract alter catabolism of adenine nucleotides and expression of ecto5'-nucleotidase / CD73 and P2 $\times 7$ and A1 receptors in the cell line MDA-MB-231.J. Ethnopharmacol. 30. pii: S03788741(16)30603-1. doi: 10.1016/j.jep.2016.08.051.

SIMÕES, C. M. O. 2007.Farmacognosia da planta ao medicamento. Porto Alegre: UFRGS.

SIMÕES, C.M. O. et al. 2001. Pharmacognosy: from plant to drug. 3.ed. Porto Alegre / Florianópolis: Publisher of UFRGS University / UFSC Publishing House.

SINGH, B.; BHAT, T.K. \& SINGH B. 2003. Potencial therapeutic applications of some antinutritional plant secondary metabolites. Journal of Agricultual and Food Chemistry,v.51,p.5579-5597.

SILVA, N.L.A.; MIRANDA, F. A. A. \& DA CONCEIÇÃO G. M. 2010. Phytochemical Screening of Cerrado Plants, from the Municipal Environmental Protection Area of Inhamum, Caxias, Maranhão. ScientiaPlena.6 (2).

SINGH, G. et al. 2014. In vitro anthelmintis efficacy of aqueous extract of Scindapsus officinalis(Roxb.) Schott fruits against
Haemonchus contortus os small ruminants.Proceedings of the National Academy of Sciences, India, Section B Biological Sciences. DOI: 10.1007/40011-014-0389-5

SUWALSKY, M. et al. 2008.Sotomayor human erythrocytes are affected in vitro by flavonoids of Aristotelia chilensis (Maqui) leaves. International Journal of Pharmaceutics 363, 85-90.

URBANIBIA, I. et al. 2013 .Anti-inflamatory and antitumoural effects of Uncaria guianensis bark. Journal of Ethnopharmacology,150:1 154-1162.

WABO PONE, J.; MBIDA, M. \& BILONG BILONG C.F.2009. In vivo evaluation of powers nematicides property ethanol extract of canthium mannii (Rubiaceae) in Heligmosomoides polygyrus rodent parasite. Vet Parasitol. Dez 3; 166 (1-2): 103-7, doi: 10.1016/ J.vetpar.2009.07.048.

WABO PONE, J.; BILONG BILONG, C.F. \& MPOAME M.2010. In vitro nematicide canthium extracts mannii (Rubiaceae), at different stages of Heligmosomoides polygyrus life cycle (Nematoda, Heligmosomatidae). J Helminthol. Jun; 84 (2): 156-65, doi: 10,1017 / SoO22149X09990435.

ZAROS, L.G. et al. 2014.Response of resistant and susceptible Brazi-lian Somalis crossbreed sheep naturally infected by Haemonchus contortus. Parasitol. Res. 113(3):1155-1161. 